\title{
A Multimethod Approach towards Assessing Urban Flood Patterns and Its Associated Vulnerabilities in Singapore
}

\author{
Winston T. L. Chow, ${ }^{1,2}$ Brendan D. Cheong, ${ }^{1}$ and Beatrice H. Ho ${ }^{1}$ \\ ${ }^{1}$ Department of Geography, National University of Singapore, AS2, No. 03-01, 1 Arts Link, Kent Ridge, Singapore 117570 \\ ${ }^{2}$ Institute of Water Policy, Lee Kuan Yew School of Public Policy, National University of Singapore, 469C Bukit Timah Road, \\ Wing A, Level 2, Oei Tiong Ham Building, Singapore 259772
}

Correspondence should be addressed to Winston T. L. Chow; winstonchow@nus.edu.sg

Received 14 December 2015; Revised 5 April 2016; Accepted 23 May 2016

Academic Editor: Huan Wu

Copyright (C) 2016 Winston T. L. Chow et al. This is an open access article distributed under the Creative Commons Attribution License, which permits unrestricted use, distribution, and reproduction in any medium, provided the original work is properly cited.

\begin{abstract}
We investigated flooding patterns in the urbanised city-state of Singapore through a multimethod approach combining station precipitation data with archival newspaper and governmental records; changes in flash floods frequencies or reported impacts of floods towards Singapore society were documented. We subsequently discussed potential flooding impacts in the context of urban vulnerability, based on future urbanisation and forecasted precipitation projections for Singapore. We find that, despite effective flood management, (i) significant increases in reported flash flood frequency occurred in contemporary (post-2000) relative to preceding (1984-1999) periods, (ii) these flash floods coincide with more localised, "patchy" storm events, (iii) storms in recent years are also more intense and frequent, and (iv) floods result in low human casualties but have high economic costs via insurance damage claims. We assess that Singapore presently has low vulnerability to floods vis-à-vis other regional cities largely due to holistic flood management via consistent and successful infrastructural development, widespread flood monitoring, and effective advisory platforms. We conclude, however, that future vulnerabilities may increase from stresses arising from physical exposure to climate change and from demographic sensitivity via rapid population growth. Anticipating these changes is potentially useful in maintaining the high resilience of Singapore towards this hydrometeorological hazard.
\end{abstract}

\section{Introduction}

Since the mid-20th century, the gradual and extensive movement of people from rural (or undeveloped) to urban (developed) areas, combined with the physical consequences of this migration, has been a distinct feature of the Anthropocene epoch [1]. This urbanisation process has a remarkable global extent; since 2007 , more than $50 \%$ of global populations reside in cities, and demographic projections indicate that urbanisation rates in major African and Asian cities over the next decade will continue to accelerate [2]. An obvious consequence is changes towards land use and land cover (LULC), which explicitly manifest through direct human modifications of various terrestrial surfaces (e.g., deforestation of forest biomes and damming of river channels). The clearest illustration of LULC conversion occurs within cities and other large urban agglomerations, where construction of buildings and roads and the activities of human economic activity directly but inadvertently affect climate properties such as near-surface temperature and wind-speed at local or regional spatial scales [3].

Apart from elevated temperatures observed within cities that is the ubiquitous urban heat island (UHI) effect [4], LULC change via urbanisation also alters hydrometeorological processes at both the surface and its overlying atmosphere. For instance, the UHI and increased roughness associated with cities vis-à-vis its rural surroundings, as well as with larger aerosol emissions from urban metabolism processes (i.e., through industrial and vehicular emissions), potentially influencing precipitation characteristics above cities. In several cases, these result in clear variations of frequency, magnitude, and spatial heterogeneity of urban-induced precipitation across city-wide [5] and regional scales [6]. At the surface, removal of vegetation and subsequent replacement 


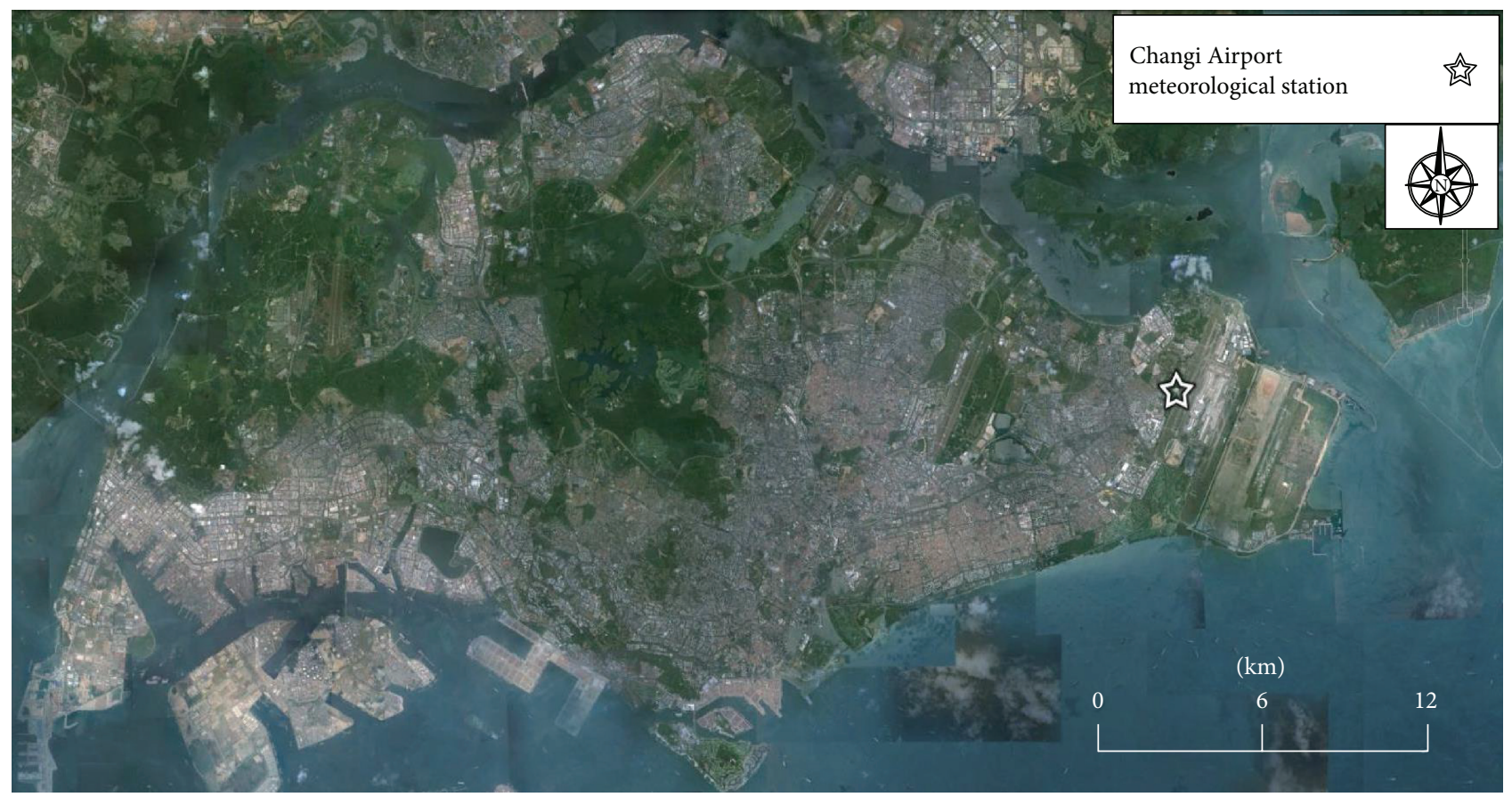

Figure 1: True colour map of Singapore in 2015 with location of Changi Airport meteorological station (the WMO station of record for Singapore) marked (source [36]).

by concrete and asphalt surfaces generally decrease urban soil porosity and permeability. Existing preurban watersheds and drainage networks may also be artificially altered and managed through either canalisation or the implementation of sewerage systems. Consequently, the net result on urban hydrology is that (i) reductions occur for local interception, infiltration, percolation, lag times, and storage through surface depressions within soil and (ii) increases in surface runoff volumes, peak flows, and flow variability ensue [7]. Greater urban sprawl with considerable soil sealing or surface "water-proofing" also corresponds with increases in urban flood risk; during high-intensity precipitation events, discharge and runoff volumes may exceed the capacity of canals and sewer systems, resulting in localised ponding or flash flood events. Further, the reduction in lag time likely reduces the effectiveness of advisories or warnings of flash floods towards populations residing in flood prone areas.

An extreme example of urbanisation can be seen in the equatorial $\left(1^{\circ} \mathrm{N} 104^{\circ} \mathrm{E}\right)$ island city-state of Singapore (Figure 1). It is subject to a tropical rainforest Köppen $A f$ climate with two distinct monsoon seasons, one in summer (typically June to August, with winds predominantly from South or Southwest) and one in winter (generally November to January, with mostly North-easterly winds) [8]. Rainfall is abundant with no distinct dry seasons (means of total annual precipitation $\sim 2500 \mathrm{~mm} \mathrm{yr}^{-1}$; mean annual frequency of $\sim 180$ rain-days $\mathrm{yr}^{-1}$ ). Since its independence in 1965 , Singapore has underwent extensive conversion of its natural (i.e., lowland dipterocarp rainforest and coastal mangroves) and agrarian (i.e., small scale subsistence and plantation agriculture) LULC towards a metropolis in which $100 \%$ of its population reside in
TABLE 1: Change in total land area of Singapore from 1960 to 2014 (source [27]).

\begin{tabular}{lcc}
\hline Year & Land area $\left(\mathrm{km}^{2}\right)$ & Population (millions) \\
\hline 1960 & 581.5 & 1.65 \\
1965 & 581.5 & 1.89 \\
1970 & 586.4 & 2.07 \\
1975 & 596.8 & 2.26 \\
1980 & 617.8 & 2.41 \\
1985 & 620.5 & 2.74 \\
1990 & 633.0 & 3.05 \\
1995 & 647.5 & 3.52 \\
2000 & 682.7 & 4.03 \\
2005 & 697.9 & 4.27 \\
2010 & 712.4 & 5.08 \\
2014 & 718.9 & 5.47 \\
\hline
\end{tabular}

built-up areas. From 1955 to 1998, the proportion of (i) total farm area, (ii) marsh and tidal areas, and (iii) forest surface cover decreased from $\sim 35 \%$ to $<10 \%$ due to conversion to built-up urban surfaces throughout Singapore [4]. This alteration is also reflected in the southward land reclamation of its main island that has resulted in a substantial increase in land surface area by almost 25\% since 1960 (Table 1).

Singapore's extensive urbanisation has been the focus of concerted study into the influence of LULC change on its climate, particularly in terms of UHI [9], and aerosol pollution [10]. Quantitatively, less investigation into its precipitation characteristics in an urban context exists, but past research has revealed some useful insights. For instance, changes 
to the surface hydrological cycle from LULC variation was examined by Chatterjea [11]. She assessed how the removal of previous forested land cover in facilitating construction of buildings and roads led to significant increases of sediment and runoff generation at these newly cleared sites, especially with frequent short-duration, high-intensity rainstorms typical of its equatorial climate.

Other studies have utilised Singapore's relatively extensive network of meteorological stations (compared to other low-latitude cities), which enable detailed analysis at fine spatiotemporal resolutions. Mandapaka and Qin [12, 13] obtained 30 years of hourly and daily data over an island-wide network of 49 rain gauges to examine aspects of Singapore's rainfall through probability distributions and spatial correlations of station data, with the twin objectives of understanding the rainfall variability of Singapore over different spatial and temporal resolutions. The relatively good quality of precipitation data also can be utilised for modelling validation studies; Vaid [14] utilised WRF to examine the model's performance when simulating a June 2013 extreme rainfall event in Singapore. The model results indicated that the localised heavy precipitation resulted from interactions of synoptic-scale weather systems (e.g., the summer monsoon) with a well-developed mesoscale convective system (e.g., squall-line development due to regional topography).

Lastly, Beck et al. [15] comprehensively reviewed Singapore's precipitation regime based on data from 30 stations from 1980 to 2010 and found that daily and seasonal variations are affected by changes in the El Niño Southern Oscillation (ENSO) teleconnection. During El Niño years, notable decreases in annual precipitation are likely to occur during the summer (Southwest) monsoon period, as in the case of an extreme El Niño event that took place in 1997. Conversely, during La Niña years, seasonal rainfall tends to increase, with more intense precipitation events occurring in the morning regional squall events versus typical afternoon convection storm events. They also noted a recent and significant trend towards more extremes in rainfall events; these occurred through increases both in the frequency of large storms and in the mean rainfall intensity. This finding concords with a previous study commissioned by a governmental agency, the Ministry of Environment and Water Resources (MEWR), which examined the variability of extreme rainfall in Singapore over the corresponding time period [16].

Of particular interest is the impact of climate change towards projected variations in Singapore's precipitation regime. Globally, a warmer climate unequivocally leads to increased water vapour, which is confirmed by fundamental physical climatology, empirical observational data, and numerical climate model simulations [17]. The increased water vapour leads to more intense precipitation events even if total annual precipitation is slightly reduced [18]. Within Southeast Asia, the extent of assessing changes in regional precipitation is stymied by generally poor spatial resolution of observational stations, but available data indicate that more (less) intense storms occur during the wet winter (dry summer) monsoon season [19]. The basis of future changes in regional precipitation is relatively more robust. Projected medium-term increases in monsoonal precipitation extremes based on the Coupled Model Intercomparison Project Phase 5 (CMIP5) results are very likely in Southeast Asia [20], with $95 \%$ of models indicating significant increases in frequencies of heavy monsoonal rainfall events.

Recently, there have been attempts to dynamically downscale selected CMIP5 global simulations with the HadGEM3RA regional climate model. This is to examine local impacts of climate change centred over Singapore based on the Representative Concentration Pathway (RCP) 8.5 and 4.5 scenarios [21]. While average annual rainfall in Singapore until 2100 will likely be dominated by natural variability under both RCP scenarios, most of the modelling simulations do suggest an increasing trend in the occurrence of both intensity and frequency of heavy precipitation events, as well as an upward (downward) trend in seasonal mean rainfall during the wet winter (dry summer) monsoons [22].

While the potential impacts arising from lowered seasonal precipitation and dry spells/drought in Singapore have been discussed [23], there appears to be little analysis done so far about the changing patterns of flood events in Singapore with respect to urbanisation and associated variations in precipitation patterns. When altered hydrometeorological processes are combined with changes in socioeconomic conditions implicit within Singapore's prodigious urbanisation rate, the resulting impacts on the system's vulnerability (i.e., the degree to which the system is susceptible to a particular hazard) become of interest with respect to overall urban sustainability. In particular, there is importance in understanding how the changing vulnerability of urban areaswhich is comprised by (i) its physical exposure towards changing precipitation patterns, as well as the city's (ii) sensitivity and (iii) capacity to adapt, derived from its socioeconomic characteristics-develops over space and time [24]. The corollary to understanding the patterns of vulnerability would be enhancing the urban resilience to natural hazards (i.e., the capacity of a city to withstand shock or stress arising from extreme hydrometeorological events); for instance, it can be done by adapting towards the danger through sound decision-making [25]. Municipal governments that do not fare well in responding to the implicit risks often have inefficient and ineffective strategies that heighten their population's vulnerability, for example, for flood vulnerability in the Asian city of Taipei [26].

In this context, an account of how Singapore has responded towards past changes in urban floods that is framed through its altered urban vulnerability could potentially be useful exemplars for other cities to consider and potentially apply in the context of a changing urban and global climate. Thus, in this paper we investigate how patterns of flooding in Singapore have varied over time through a novel, multimethod approach. First, we document the history of Singapore's flooding through examining (i) its precipitation data and (ii) archival newspaper and governmental records; in particular, we are interested in documenting if changes are apparent in the frequency of flash floods or in the reported impacts of floods towards Singapore society. Second, in the context of urban vulnerability, we examine and discuss the projected impacts of flooding that may arise based 
on future trajectories of urban development in Singapore, in conjunction with forecasted projections of precipitation variations at various spatial scales.

\section{Methodology}

In documenting the historical extent of flooding in Singapore, we utilised several data sources. First, we obtained hourly climate data from 1956 to 2015 recorded at the meteorological station located at Changi Airport (sited on the eastern end of Singapore) that are provided by the National Climatic Data Center (NCDC). Since January 1984, this station has been designated as the official World Meteorological Organisation (WMO) climate station for Singapore. We subsequently derived precipitation intensity data for analysis of relevant storms that are directly related to reported flood events. Second, we examined archival data from local newspapers and governmental websites pertaining to floods in Singapore. In particular, we examined newspaper reports about floods from the local English daily newspaper of record (The Straits Times), which was originally established in 1845 and has articles that are readily accessible through a large digital archive [28].

This large newspaper archive enabled us to search for flood events in Singapore deemed noteworthy enough to be reported for public interest, such as floods resulting in or causing human casualties, property damage, and disruption to traffic due to road inundation, landslides, or fallen trees from storms. While there are potential archival data issues related towards progressive increases in newspaper space that may enable more reports of floods in recent years (i.e., likely underreporting of floods in the past), we opine that this approach enables flood analyses directly relevant towards examining societal vulnerability and resilience to this hazard, as opposed to only examining storms of large intensities in the Changi precipitation data that may not translate to floods with significant societal impact. Nonetheless, we acknowledge this limitation especially in the low reports of floods that are apparent prior to 1965.

We subsequently obtained and collated a total of 262 archived articles from December 1892 until December 2015 using the search term "flood+Singapore." If reported, relevant hydrometeorological information such as (i) location and areal extent of the flood, (ii) tidal information, (iii) flood depth, and (iv) rainfall amounts from these events were recorded; however, derivation of hourly rainfall depth and intensity based on these flood reports was problematic for two reasons. Firstly, articles did not clearly indicate durations of each rainfall or storm event: that is, only total rainfall amounts are reported. Secondly, some of the reported rainfall data were from weather stations that were closer in distance to where the flood impacts occurred, rather than from Changi. Nonetheless, we compared the reported storm magnitude for recent floods that fall within the recorded data range at Changi to ascertain if the precipitation causing the flood was also measured at the WMO station of record. Indications of human injury and property damage mentioned in the database of newspaper reports, as well as if the flood was explicitly described as a "flash flood," were also documented.
To assess the quality of the constructed flood database, we also examined publically available records of recent (post2000) floods maintained by the Public Utilities Board (PUB) at their website [29]. In Singapore, the PUB is the national water agency under the purview of MEWR that manages the water infrastructure, including storm-water drainage and sewerage treatment. Part of its role is in managing water resources includes (i) planning adequate drainage ahead of new developments in conjunction with relevant stakeholders, (ii) ensuring that developments follow a code of practice that stipulates adequate drainage requirements, for example, minimum platform and crest level for buildings and entrances to underground facilities, (iii) the continual widening, deepening, and maintenance of existing drains and canals, and (iv) implementing a system of island-wide monitoring and flood detection, coupled with the broad dissemination of flood warnings and advisories [30-32]. A holistic integration with other governmental agencies that have relevant impact with LULC change is a strong feature of PUB's water resource management. Through investments totalling > S $\$ 2$ billion (>USD 1.42 billion), the PUB has considerably reduced flood prone areas in Singapore from about 3,200 ha in the 1970 s to about 34 ha in 2015 with intensive efforts in land and drainage management [33]. This significant reduction is remarkable, despite the increased "water-proofing" of the urban surface in Singapore that alters the prevailing hydrometeorological regime, that is, increased frequencies of urban flood episodes.

The PUB also provides a simple, nonmeteorological definition of flash floods, which are localised floods (arising from heavy rainfall) that are constrained within the immediate drainage catchment, and also subsides within an hour [34]. This definition is similar to that proposed by the US National Weather Service, which defines flash floods as "a flood which follows within a few hours (usually less than 6 hours) of heavy or excessive rainfall, dam or levee failure, or the sudden release of water impounded by an ice jam" [35]. The common features implicit in these definitions are that flash floods in Singapore are linked to short-lived but intense storm events, which cause greater storm-water peak flow especially in built-up or low-lying areas, and are especially worsened if these occur during high tide conditions. We hereby use this definition of flash floods in this study.

\section{Results}

3.1. Hydrometeorological Summary of Singapore Flood History from 1892 to 2015. Through the archival database, a total of 262 flood events spanning from December 1892 until December 2015 were listed (Figure 2). These were separated into flash flood versus nonflash flood categories as explicitly mentioned in either the respective media article or the PUB archive. These floods were a regular occurrence from 1965 to 2015 in which Singapore was an independent state. During this fifty-year period, 212 total flood events were reported in the media archives, with only seven years that were absent of recorded newsworthy flood events. This translated to a mean of about 4.2 reported floods per year. 64 reported floods or 


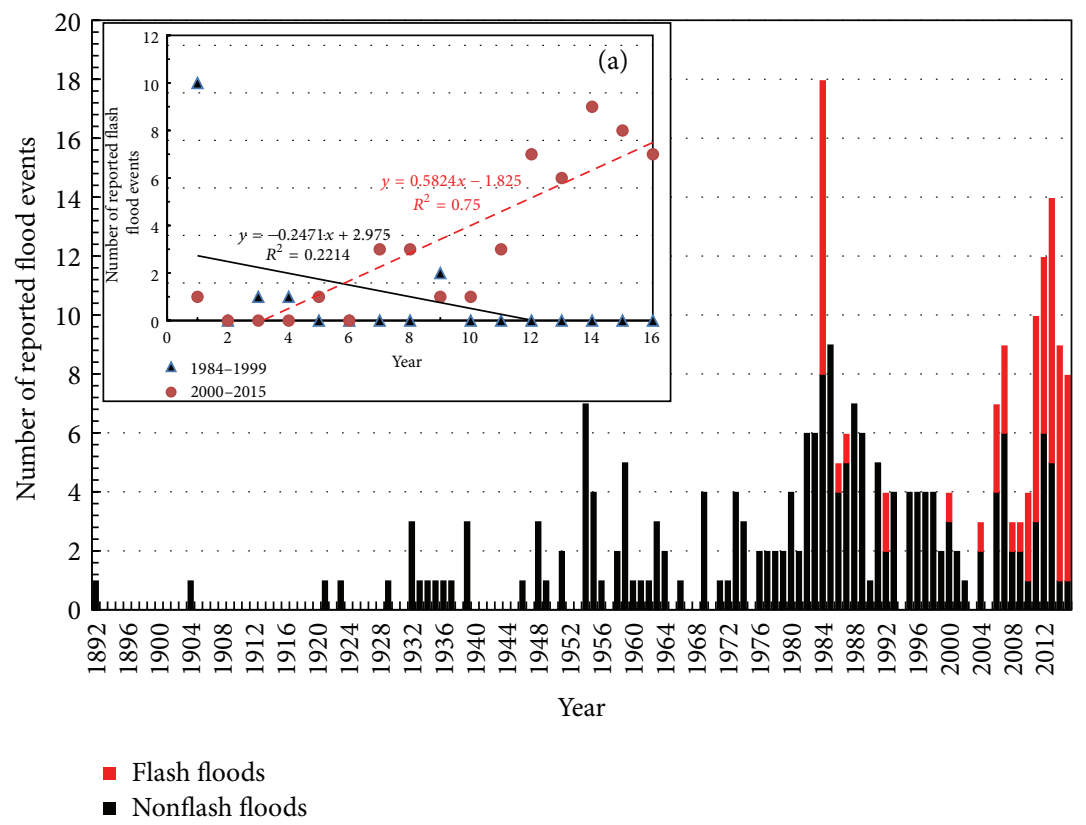

Figure 2: Frequency of total number of reported Singapore floods, categorised into flash floods and nonflash floods, listed in The Straits Times archive from 1892 to 2015. Insert (a) shows linear trend, depicted by Ordinary Least Squares (OLS), of reported flash floods from 1984 to 1999 (black) and 2000 to 2015 (red dashed) that is also based on the archived flood dataset.

$30.2 \%$ of all events during these fifty years were defined as flash floods.

A small majority of reported floods in the database (56\%) occurred during both monsoon seasons, with $36 \%$ of all floods in the winter (NE) monsoon and $20 \%$ in the summer (SW) monsoon. Flooding events in the winter monsoon usually arise from prolonged storm events with relatively low precipitation intensities; when reported, durations of these storms range from 2 to $48 \mathrm{~h}$, with mean hourly intensities of $\sim 20.2 \mathrm{~mm} \mathrm{~h}^{-1}$. In contrast, summer monsoon floods originate from relatively brief storms (2$7 \mathrm{~h})$ with marginally higher mean intensities $\left(\sim 39.3 \mathrm{~mm} \mathrm{~h}^{-1}\right)$ that usually arise from predawn squall development along the Straits of Malacca west of Singapore. High tide conditions simultaneously occurring during storm events were also explicitly mentioned for 34 floods in the database as a contributing factor towards flooding. The most number of floods (18, of which 10 were classified as flash floods) occurred in 1984, a year in which weak La Niña conditions occurred regionally. Notably, above-average total annual precipitation was observed in Singapore ( $2900 \mathrm{~mm}$ compared to the 19611990 normal of $2150 \mathrm{~mm}$ ) in 1984.

There appears to be a distinct and recent transition towards more flash floods in Singapore relative to nonflash floods in the data. We analysed two distinct 16 -year periods for the frequency of flash floods-a preceding period starting from 1984, which is when the term "flash flood" was first mentioned in The Straits Times, until 1999, and a contemporary period from 2000 to 2015 . These periods were subject to independent-samples unequal variances $t$-test to compare if differences were present in the frequency of flash floods being reported. A significant difference of flash flood frequency at the $p=0.05$ level was discerned in the contemporary $(\bar{u}=3.13, \sigma=3.20,95 \% \mathrm{CI}=1.42,4.83)$ versus the preceding period $(\bar{u}=0.875, \sigma=2.50,95 \% \mathrm{CI}=0,2.20)$. In contrast, there was no significant difference in the means of all flood frequencies in the preceding $(\bar{u}=5.19, \sigma=4.05,95 \% \mathrm{CI}=$ $3.03,7.35)$ and contemporary $(\bar{u}=5.56, \sigma=4.35,95 \%$ $\mathrm{CI}=3.24,7.88)$ periods. An increasing strong linear trend for reported flash flood frequency in the contemporary period is also apparent $\left(R^{2}=0.75\right.$, Figure $\left.2(\mathrm{a})\right)$, especially when compared to the weak decreasing trend from the preceding period.

These results suggest that flash floods-at least those with notable impact in Singapore society that are reported in the local newspaper of record-are becoming a more common occurrence in recent times. Usually, increases in flash flood frequency in the urban context can be attributed towards LULC conversion that result in an earlier stormwater peak, that is, reduced lag time, and increases in surface runoff and discharge relative to infiltration during all precipitation events. This correspondence in more frequent flash floods should also apply to Singapore especially with its rapid LULC conversion and increased population that were documented in Table 1. However, effective urban storm-water drainage management implemented by the PUB that includes extensive canalisation networks of waterways, drains, and reservoirs totalling $8000 \mathrm{~km}$ in length [37] appears to be successful in reducing impacts of increased runoff from land cover change, but not so for the impacts of relatively infrequent flood events reported in the archives.

That said, increases in reported flash floods reported in the archives could arise from other causes besides rapid urbanisation. A likely factor could be the long-term variation in precipitation patterns driving these local flooding events. The contemporary increase in flash floods corresponds with 

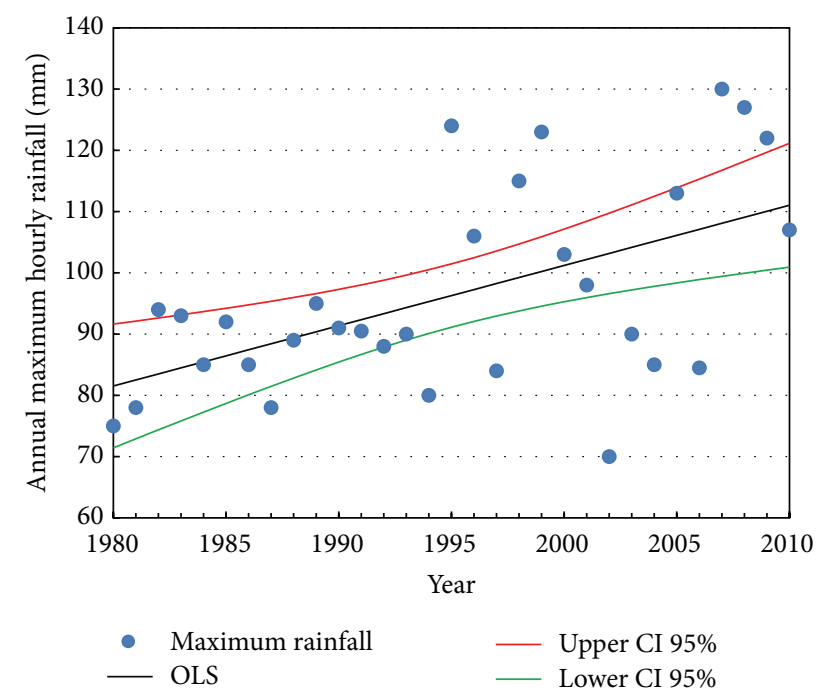

(a)

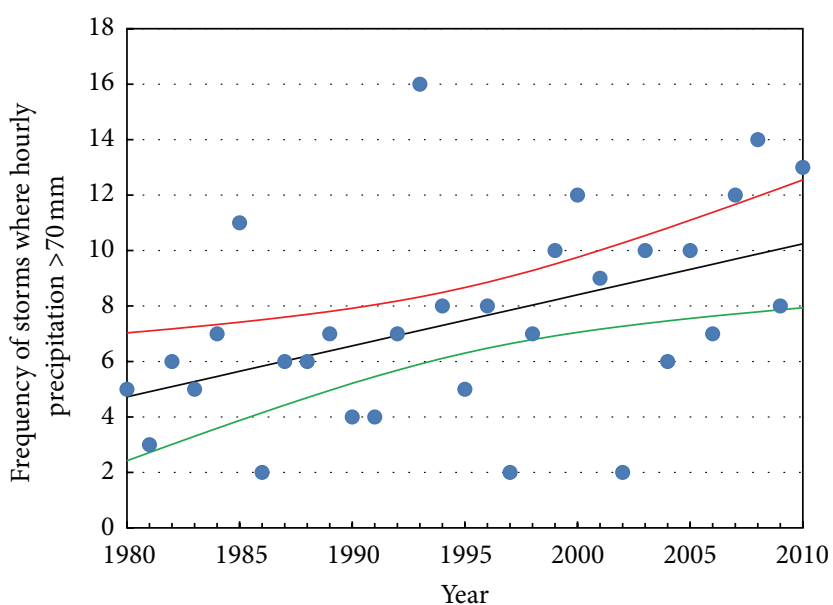

- Storm $>70 \mathrm{~mm} \quad$ Upper CI $95 \%$

(b)

FIGURE 3: (a) Maximum annual hourly rainfall and (b) frequency of large storms, defined as hourly precipitation intensity if $>70 \mathrm{~mm} \mathrm{~h}^{-1}$, that were measured across 28 stations from 1980 to 2010. The mean OLS linear trends and the respective upper and lower 95\% confidence intervals are also depicted (source: figures based from data reported in [16]).

previous data analysis done by the MEWR on the changing precipitation dynamics that are observed in Singapore [16]. Specifically, trends of both hourly maximum precipitation and frequency of large storms, defined as hourly total precipitation larger than $70 \mathrm{~mm}$, have been significantly increasing on an annual basis since 1980 by approximately $9.8 \mathrm{~mm}$ and 1.8 days per decade, respectively (Figure 3 ). Attribution of the more frequent, and more intense, rainfall events being recorded island-wide being is not investigated herein, but this trend accords with expected changes in precipitation patterns from increased greenhouse gases at global scales [17].

3.2. Key Aspects of Floods in Singapore. Specific characteristics pertaining to each reported flood in the database can be viewed in the supplemental material (Table S1 in Supplementary Material available online at http://dx.doi.org/ 10.1155/2016/7159132); however, selected flood events that had notable precipitation intensities and/or had direct impact on Singapore's society through deaths, injuries, infrastructural damage, and transport disruption are listed in chronological order in Table 2. Three aspects of these floods are apparent. First, distinct variations in rainfall intensities reported in the newspaper reports versus those recorded at the Changi meteorological station are often observed; the difference is readily apparent in contemporary flood events post-2000. This result suggests that recent precipitation events-at least those that result in notable flooding episodes, including the June 2013 storm and resulting flood modelled by Vaid [14] appear to be more localised or "patchy" in spatial extent relative to the entire island; that is, precipitation intensities occurring at Changi do not approach the magnitude reported in the media article.

Based on 171 floods reported in Table S1 after 1984 (when Changi station was deemed as the official station of record), a total of 36 flood events had no recorded rainfall at Changi
(13 events after the year 2000). Further, the list of floods post-2000 in Table 2 indicates that measured precipitations at Changi are often considerably less than magnitudes reported in the news archives from rainfall gauges located in close proximity to the flood events. The implication, therefore, is that flood hazard analyses, or planning for flood management in Singapore based solely on meteorological data from the station of record, could result in the critical omission of these isolated storms.

Second, a relatively low number of floods- 15 out of 85 contemporary floods post-2000-that occur during increasing or high tide conditions could suggest that extensive investments in flood management by the PUB have been effective. These measures include the inclusion of on-site storm-water detention tanks in building codes for building developers [38], development and construction of urban storm-water diversion canals, for example, the Stamford Diversion Canal that was designed and constructed after a series of floods affecting central Singapore in June 2010 [39], and tidal gates that pump excess storm-water flow out to sea even during high tide conditions, for example, the Marina Barrage in South Singapore [40].

Third, compared to neighbouring Southeast Asian nations, for example, the October-November 2011 Thailand floods where more than 500 deaths occurred [41], flooding impacts in Singapore are relatively minor in terms of human casualties. For instance, seven deaths were reported in the most severe flood from the archives that occurred in 1978, where $512.4 \mathrm{~mm}$ of rain fell over a $24 \mathrm{hr}$ period (Per The Straits Times, reports from media published in other languages indicate that eight deaths resulted from the 1978 flood). The relatively low death toll from all floods in the archives, especially post-1965, can clearly be attributed to the water management practices of the PUB. This applies to the development of physical infrastructure development not 
TABLE 2: Selected characteristics of notable flood events with significant impact occurring within Singapore. Rainfall, location, and damage are based on reported information from the relevant archived Straits Times article. Flash floods as defined in this study are italicised.

\begin{tabular}{|c|c|c|c|}
\hline Date & Rainfall intensity (Changi airport) $^{\mathrm{a}}$ & Location $^{\mathrm{b}}$ & Reported damage and other relevant details \\
\hline \multicolumn{4}{|c|}{ Pre-1965 } \\
\hline 22 March 1936 & $80.26 \mathrm{~mm} / 40 \mathrm{mins}(\mathrm{NA})$ & Central & $\begin{array}{l}\text { (i) Flooding of roads and houses } \\
\text { (ii) Traffic jams } \\
\text { (iii) Falling trees } \\
\text { (iv) Dislocation of telephone system }\end{array}$ \\
\hline 23 October 1954 & $101.6 \mathrm{~mm} / 2.5$ hours (NA) & Central & $\begin{array}{l}\text { (i) Stoppage of airport flights } \\
\text { (ii) Marooned/stranded cars }\end{array}$ \\
\hline 13 November 1963 & $42.93 \mathrm{~mm} / 3$ hours $(0.3 \mathrm{~mm})$ & South & $\begin{array}{l}\text { (i) Power failure in several places } \\
\text { (ii) Traffic jams }\end{array}$ \\
\hline \multicolumn{4}{|c|}{$1965-1980$} \\
\hline 11 December 1969 & $467 \mathrm{~mm} / 17$ hours (NA) & Island-wide & $\begin{array}{l}\text { (i) } 5 \text { killed } \\
\text { (ii) } 3100 \text { people lost their homes } \\
\text { (iii) Flood depth up to } 2.5 \mathrm{~m} \\
\text { (iv) } S \$ 4.3 \text { million damage ( } 2015 \text { value of } S \$ 16 \text { million) }\end{array}$ \\
\hline 23 September 1971 & $58.4 \mathrm{~mm} / 2$ hours (NA) & Central & $\begin{array}{l}\text { (i) Power failure } \\
\text { (ii) Landslides } \\
\text { (iii) Traffic jams and road accidents } \\
\text { (iv) Airport delays }\end{array}$ \\
\hline 2 December 1978 & $512 \mathrm{~mm} / 24$ hours (NA) & Island-wide & $\begin{array}{l}\text { (i) Singapore's “worst" flood on record } \\
\text { (ii) } 7 \text { deaths, } 1000 \text { people evacuated } \\
\text { (iii) Flood depth reached } 2 \mathrm{~m} \\
\text { (iv) Disruption of power and telephone lines } \\
\text { (v) } 50 \text { roads sealed off } \\
\text { (vi) } S \$ 10 \text { million damages ( } 2015 \text { value of } S \$ 22.5 \text { million) } \\
\text { (vii) Flooding coinciding with high tide conditions }\end{array}$ \\
\hline \multicolumn{4}{|c|}{ 1981-1999 } \\
\hline 22 August 1983 & $\begin{array}{c}178.1 \mathrm{~mm} / 2 \text { hours }(182.0 \mathrm{~mm} / 3 \\
\text { hours) }\end{array}$ & East & (i) Flooding of airport car park \\
\hline 2 March 1984 & $\begin{array}{c}112.1 \mathrm{~mm} / 12 \text { hours }(119.0 \mathrm{~mm} / 3 \\
\text { hours })\end{array}$ & West and Central & $\begin{array}{l}\text { (i) Massive traffic jams } \\
\text { (ii) Landslides and fish farms affected } \\
\text { (iii) Blackouts throughout the island } \\
\text { (iv) University exams delayed }\end{array}$ \\
\hline 18 January 1989 & $94.9 \mathrm{~mm} / 8$ hours (No rain reported) & Central & (i) Traffic jams and stranded people \\
\hline 25 February 1997 & $98 \mathrm{~mm} / 1$ hour $(27.0 \mathrm{~mm} / 3$ hours $)$ & East & (i) Blackouts, flooded houses, and damaged belongings \\
\hline 12 July 1998 & $165 \mathrm{~mm} / 3.5$ hours $(34.0 \mathrm{~mm} / 3$ hours $)$ & East & (i) Shops damaged \\
\hline 6 January 1999 & NA (10.9 mm/3 hours) & South & (i) Business goods damaged \\
\hline 22 December 1999 & NA (12.9 mm/24 hours) & $\begin{array}{l}\text { South and } \\
\text { Central }\end{array}$ & $\begin{array}{l}\text { (i) Shops flooded } \\
\text { (ii) Businesses disrupted } \\
\text { (iii) Flooding coinciding with high tide conditions }\end{array}$ \\
\hline \multicolumn{4}{|r|}{ 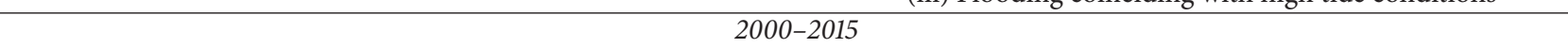 } \\
\hline 6 April 2000 & $166 \mathrm{~mm} / 1.5$ hours $(3.7 \mathrm{~mm} / 24 \mathrm{hrs})$ & Central & $\begin{array}{l}\text { (i) } 2 \text { deaths } \\
\text { (ii) "1-in-100 year storm" }\end{array}$ \\
\hline 16 June 2010 & $100 \mathrm{~mm} / 3$ hours $(38 \mathrm{~mm} / 6$ hours $)$ & Central & $\begin{array}{l}\text { (i) Flood depth } 0.3 \mathrm{~m} \\
\text { (ii) Traffic jam } \\
\text { (iii) Shops damaged }\end{array}$ \\
\hline 25 June 2010 & $100 \mathrm{~mm} / 1$ hour $(26 \mathrm{~mm} / 3$ hours $)$ & Central & $\begin{array}{l}\text { (i) Traffic congestion } \\
\text { (ii) Insurance claims of } S \$ 23 \text { million (2015 value of S } \$ 25.3 \\
\text { million) }\end{array}$ \\
\hline 5 May 2012 & $68.6 \mathrm{~mm} / 0.5$ hours $(0.2 \mathrm{~mm} / 3$ hours $)$ & Central and North & (i) Flood depth $0.25 \mathrm{~m}$ \\
\hline 5 September 2013 & $\begin{array}{c}102.8 \mathrm{~mm} / 1.5 \text { hours }(25.2 \mathrm{~mm} / 6 \\
\text { hours })\end{array}$ & West & $\begin{array}{l}\text { (i) Part of major highway shut down } \\
\text { (ii) Traffic jam } \\
\text { (iii) Flood depth } 0.5 \mathrm{~m} \\
\text { (iv) Flooding coinciding with high tide conditions }\end{array}$ \\
\hline 29 July 2014 & $49.4 \mathrm{~mm} / 30$ mins $(29 \mathrm{~mm} / 6$ hours $)$ & Central & (i) Traffic jam \\
\hline
\end{tabular}

${ }^{a}$ When applicable, precipitation data in parenthesis are reported from the WMO meteorological station of record at Changi airport.

${ }^{\mathrm{b}}$ Specific locations in parenthesis are categorised into specific sectors of Singapore (north, south, east, west, and central). 


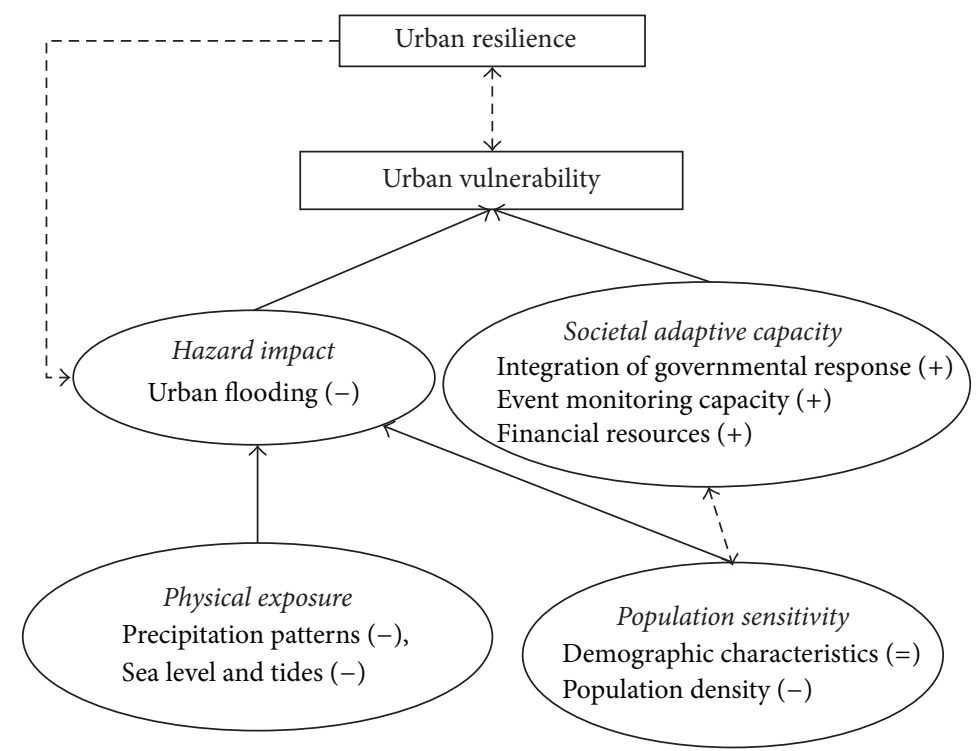

FIGURE 4: Framework of Singapore's urban vulnerability to flooding based on previous conceptual frameworks in [17, 25]. The ovals are component factors of overall vulnerability with relevant physical and social attributes italicised. The impacts of such attributes towards overall vulnerability are positive $(+)$, negative $(-)$, or neutral $(=)$. Solid lines indicate direct connections between components with the direction being indicated by the arrowhead, while dashed connections indicate potential feedbacks. Lastly, the state of vulnerability directly affects resilience to flooding, which feedbacks on the magnitude of the flood hazard impact.

only through extensive canalisation within flood prone areas and rapid flood detection instrumentation and monitoring, but also through advisories widely broadcasted across media platforms that (i) warn the public of flash floods and (ii) also advise on the relevant course of individual action [42]. Instead, the flood impacts are greater towards water damage to property and transport disruption due to inundation of surface roads. This was most evident in a series of floods occurring in 2010 that took place in the central areas of Singapore Island in which most of the commercial district is located. While no human injuries were reported, there was substantial property damage to 100 shops and 48 vehicles along roads flooded by the storm that resulted in insurance claims totalling S\$23 (USD 16.3) million in 2010 (S\$25.3 (USD 18) million in 2015) [43].

\section{Discussion: Future Vulnerabilities of Urban Flooding in Singapore}

The archival analysis strongly suggests that PUB's integrated approach to floodwater management in Singapore has largely been successfully applied over the past 50 years. Despite the rapid LULC change in a city exposed to frequent and intense storm events, flooding hazards have largely been minimised in impact through effective adaptation techniques, especially with low reported loss of life. In the context of urban vulnerability analysis (Figure 4), notwithstanding the higher physical exposure (e.g. changing precipitation patterns) and increasing sensitivity (e.g., from greater population densities) leading to potentially large impacts, there is considerably strong adaptive capacity from the actions of PUB that have considerably reduced the urban vulnerability of Singapore towards flood hazards. The net result is a resilient system in
Singapore that minimises the impacts and risks associated with present-day flooding, especially with respect to historical conditions.

However, the pattern of vulnerability suggested in Figure 4 may superficially be implied as static and should not be considered as such. With increasing greenhouse gases emissions resulting in the intensification of the hydrological cycle, there should be concern of how altered precipitation regimes in Southeast Asia, such as those modelled and described by [22], will alter the existing urban vulnerability to floods. Apart from the direct influence of increased greenhouse gas forcing on regional precipitation, a further complication is that recent research indicates that frequencies of extreme ENSO [44] and Indian Ocean Dipole events [45] are likely to be altered up to 2100 . These teleconnections have considerable historical influence on the variability of regional rainfall patterns [8] and may exacerbate conditions that favour intense precipitation leading to flooding. The increased uncertainty brought about by these physical exposure factors should be considered into future assessments of flood vulnerability and resilience.

Another important consideration should be focused on sea level rise (SLR) and its impact on floods in Singapore. Wong [46] analysed local impacts from an abnormal high tide event that took place in February 1974 on low-lying areas in Singapore as an analogue for $1 \mathrm{~m}$ global SLR conditions; he indicated the importance of tidal gates to minimise tidal inflow from reducing the effectiveness of storm-water drainage channels. While these explicit adaptation measures to improve Singapore's resilience to urban flooding have been developed in accordance with IPCC AR5 SLR projections, for example, reclaimed land being $2.25 \mathrm{~m}$ above highest tide level in Singapore [47], recent post-AR5 research suggests 
that this physical exposure factor may be magnified. Analyses of potential acceleration of melting continental ice sheets, for example, in West Antarctica [48, 49], raise the likelihood of future SLR being higher than the conservative IPCC [17] estimates, with subsequent negative impacts on urban flood vulnerability.

Apart from physical exposure factors, changes in future population growth in Singapore will impinge on its sensitivity towards flood hazards. Urbanisation rates are not expected to diminish in rate over the next few decades. Extensive municipal planning has been put into place for the medium term, both in terms of LULC use up until 2030 [50] and towards preparing population growth in that same timeframe for a projected maximum of 6.9 million [51]. The net result of which is likely to be substantial increases in population density, as well as in areas prone to flash flooding events that will require substantial investments towards flood management. The sensitivity of population towards hydrometeorological hazards would, in all likelihood, be negatively affected.

The corollary to these factors would be that present net positives in adaptive capacity towards urban flooding must be maintained, if not improved, to ensure that the low vulnerability/high resilience vis-à-vis Singapore's flood context persists in the future. The approach done by the PUB, such as with foresight of continual investments in drainage improvement, combined with regular infrastructural maintenance, has largely succeeded and would probably be required at larger scales in the future. Anticipating the impacts based on the vulnerability framework in this paper may be a good step towards this end; based on the complicated and uncertainty of the factors raised above, however, it is uncertain to which extent an intelligent urban design and urban managementeven successfully applied in Singapore-can buffer these negative effects of flooding.

\section{Conclusions}

This study examines historical flood hazard impacts upon a major city-state in Singapore through a combination of archival records and meteorological station data analysis. The combined methodology enables additional insights into flood impacts that are precluded by studies that only examine meteorological data. The key results indicate that, in Singapore's case, the patterns of flooding have been altered over time; the incidence of flash floods relative to nonflash floods in the archival data appears to be increasing in recent years, as noted by the meteorological data analysed by MEWR [16], but the impacts of flash floods appear to be attenuated by the integrated, and hitherto effective, flood management from the PUB that increases the adaptive capacity of Singapore's vulnerability to this hazard.

The steps taken in Singapore that result in the low vulnerabilities, and increased resilience, to flood hazards over the past 50 years could be examined as a case study by other rapidly urbanising cities or city-states. In particular, the holistic integration of decision-making and effective water resource management simultaneously minimises the risk and maximises the resilience towards floods. That said, altered regional hydrometeorological conditions brought upon by climate change and future alterations to Singapore's demographic composition may result in the need for further anticipatory measures towards maintaining the city-state's resilience to floods.

\section{Competing Interests}

The authors declare that they have no competing interests.

\section{Acknowledgments}

A major impetus for this paper stemmed from discussions between the authors with Dr. Alan Ziegler and Dr. Robert Wasson from NUS and Ms. Claire Kennedy (AON Benfield) during the Future Floods Workshop organised by the Faculty of Arts and Social Sciences Environment Cluster (NUS) and AON Benfield in February 2015. The authors sincerely thank these individuals for their suggestions. WTLC's research is supported by the NUS through research Grant R-109-000162-133.

\section{References}

[1] P. J. Crutzen, “The Anthropocene," in Earth System Science in the Anthropocene, E. Ehlers and T. Krafft, Eds., Springer, Berlin, Germany, 2006.

[2] United Nations, Department of Economic and Social Affairs, Population Division, World Urbanization Prospects: The 2014 Revision, Highlights (ST/ESA/SER.A/352), http://esa.un.org/ unpd/wup/highlights/wup2014-highlights.pdf.

[3] T. R. Oke, Boundary Layer Climates, Methuen, New York, NY, USA, 1987.

[4] W. T. L. Chow and M. Roth, "Temporal dynamics of the urban heat island of Singapore," International Journal of Climatology, vol. 26, no. 15, pp. 2243-2260, 2006.

[5] J. M. Shepherd, "A Review of current investigations of urbaninduced rainfall and recommendations for the future," Earth Interact, vol. 9, no. 12, pp. 1-27, 2005.

[6] M. Georgescu, P. E. Morefield, B. G. Bierwagen, and C. P. Weaver, "Urban adaptation can roll back warming of emerging megapolitan regions," Proceedings of the National Academy of Sciences of the United States of America, vol. 111, no. 8, pp. 29092914, 2014.

[7] S. E. Brun and L. E. Band, "Simulating runoff behavior in an urbanizing watershed," Computers, Environment and Urban Systems, vol. 24, no. 1, pp. 5-22, 2000.

[8] M. Fong, The Weather and Climate of Singapore, Meteorological Services Singapore, Singapore, 2012.

[9] M. Roth and W. T. L. Chow, "A historical review and assessment of urban heat island research in Singapore," Singapore Journal of Tropical Geography, vol. 33, no. 3, pp. 381-397, 2012.

[10] E. Velasco and M. Roth, "Review of Singapore's air quality and greenhouse gas emissions: current situation and opportunities," Journal of the Air \& Waste Management Association, vol. 62, no. 6, pp. 625-641, 2012.

[11] K. Chatterjea, "The impact of tropical rainstorms on sediment and runoff generation from bare and grass-covered surfaces: a plot study from Singapore," Land Degradation and Development, vol. 9, no. 2, pp. 143-157, 1998. 
[12] P. V. Mandapaka and X. Qin, "Analysis and characterization of probability distribution and small-scale spatial variability of rainfall in singapore using a dense gauge network," Journal of Applied Meteorology and Climatology, vol. 52, no. 12, pp. 27812796, 2013.

[13] P. V. Mandapaka and X. Qin, "A large sample investigation of temporal scale-invariance in rainfall over the tropical urban island of Singapore," Theoretical and Applied Climatology, vol. 122, no. 3-4, pp. 685-697, 2014.

[14] B. H. Vaid, "Numerical simulations and analysis of June 16, 2010 heavy rainfall event over Singapore using the WRFV3 model," International Journal of Atmospheric Sciences, vol. 2013, Article ID 825395, 8 pages, 2013.

[15] F. Beck, A. Bárdossy, J. Seidel, T. Müller, E. Fernandez Sanchis, and A. Hauser, "Statistical analysis of sub-daily precipitation extremes in Singapore," Journal of Hydrology: Regional Studies, vol. 3, pp. 337-358, 2015.

[16] MEWR (Ministry of the Environment and Water Resources), Report on Key Conclusions and Recommendations of the Expert Panel on Drainage Design and Flood Protection Measures, 2012, http://www.pub.gov.sg/managingflashfloods/floodResiliencePlan/Documents/fullReport.pdf.

[17] IPCC (Intergovernmental Panel on Climate Change), "Summary for policymakers," in Climate Change 2013: The Physical Science Basis. Contribution of Working Group I to the Fifth Assessment Report of the Intergovernmental Panel on Climate Change, T. F. Stocker, D. Qin, G.-K. Plattner et al., Eds., Cambridge University Press, Cambridge, UK, 2013.

[18] K. E. Trenberth, "Framing the way to relate climate extremes to climate change," Climatic Change, vol. 115, no. 2, pp. 283-290, 2012.

[19] J. H. Christensen, K. K. Krishna, E. Aldrian et al., "Climate phenomena and their relevance for future regional climate change," in Climate Change 2013: The Physical Science Basis. Contribution of Working Group I to the Fifth Assessment Report of the Intergovernmental Panel on Climate Change, T. F. Stocker, D. Qin, G.-K. Plattner et al., Eds., Cambridge University Press, Cambridge, 2013.

[20] Y. Hijioka, E. Lin, J. J. Pereira et al., “Asia," in Climate Change 2014: Impacts, Adaptation, and Vulnerability. Part B: Regional Aspects. Contribution of Working Group II to the Fifth Assessment Report of the Intergovernmental Panel on Climate Change, V. R. Barros, C. B. Field, D. J. Dokken et al., Eds., pp. 1327-1370, Cambridge University Press, Cambridge, UK, 2014.

[21] C. Marzin, A. Hines, J. Murphy, C. Gordon, and R. Jones, “Chapter 1 executive sumamry," in Singapore's Second National Climate Change Study_Phase 1, C. Marzin, R. Rahmat, D. Bernie et al., Eds., 2015, http://ccrs.weather.gov.sg/publications-secondNational-Climate-Change-Study-Science-Reports.

[22] R. Jones, G. Redmond, T. Janes et al., "Climate change projections," in Singapore's Second National Climate Change Study_Phase 1, C. Marzin, R. Rahmat, D. Bernie et al., Eds., chapter 5, 2015, http://ccrs.weather.gov.sg/publications-secondNational-Climate-Change-Study-Science-Reports.

[23] A. D. Ziegler, J. P. Terry, G. J. H. Oliver et al., "Increasing Singapore's resilience to drought," Hydrological Processes, vol. 28, no. 15 , pp. 4543-4548, 2014.

[24] W. T. L. Chow, W.-C. Chuang, and P. Gober, "Vulnerability to extreme heat in metropolitan phoenix: spatial, temporal, and demographic dimensions," The Professional Geographer, vol. 64, no. 2, pp. 286-302, 2012.
[25] P. Romero Lankao and H. Qin, "Conceptualizing urban vulnerability to global climate and environmental change," Current Opinion in Environmental Sustainability, vol. 3, no. 3, pp. 142149, 2011.

[26] L. Chang, K. C. Seto, and S. Huang, "Chapter 11: climate change, urban flood vulnerability, and responsibility in Taipei," in Urbanization and Sustainability, C. Boone and M. Fragkias, Eds., pp. 179-198, Springer, Berlin, Germany, 2013.

[27] Department of Statistics Singapore, Population and Population Structure, 2015, http://www.singstat.gov.sg/statistics/ browse-by-theme/population-and-population-structure.

[28] National Library Board, NewspaperSG, 2015, http://eresources .nlb.gov.sg/newspapers/default.aspx.

[29] PUB, "Recent Flash Floods," 2015, http://www.pub.gov.sg/ managingflashfloods/Pages/recent.aspx.

[30] C. Tortajada and Y. K. Joshi, "Water demand management in Singapore: involving the public," Water Resources Management, vol. 27, no. 8, pp. 2729-2746, 2013.

[31] C. Tortajada, Y. Joshi, and A. Biswas, The Singapore Water Story, Routledge/Taylor \& Francis, New York, NY, USA, 2013.

[32] PUB, "Stormwater Management Strategies," 2015, http://www .pub.gov.sg/managingflashfloods/fms/Pages/default.aspx.

[33] PUB, "The Past and the Present," 2015, http://www.pub.gov.sg/ managingflashfloods/Pages/PastPresent.aspx.

[34] PUB, "Frequently Asked Questions," 2015, http://www.pub.gov .sg/managingflashfloods/faqs/Pages/default.aspx?Print2=yes.

[35] National Oceanic and Atmospheric Administration (NOAA), Glossary of Hydrologic Terms, 2014, http://www.nws.noaa.gov/ om/hod/SHManual/SHMan014_glossary.htm.

[36] Google Earth, 2015, https://www.google.com/earth/.

[37] Public Utilities Board (PUB), Strengthening Singapore's Flood Resilience, 2013, http://www.pub.gov.sg/managingflashfloods/ FMS/Documents/FloodManagementSg.pdf.

[38] PUB, "On-Site Stormwater Detention Tank Systems," 2014, http://www.pub.gov.sg/managingflashfloods/FMS/Documents/detentionTank.pdf.

[39] J. Cheam, Forging a Greener Tomorrow, Singapore's Environmental Journey from Slum to Eco-City, Straits Times Press, Singapore, 2012.

[40] W. H. Moh and P. L. Su, "Marina Barrage-a unique 3-in-1 project in Singapore," Structural Engineering International, vol. 19, no. 1, pp. 17-21, 2009.

[41] A. D. Ziegler, H. S. Lim, C. Tantasarin, N. R. Jachowski, and R. Wasson, "Floods, false hope, and the future," Hydrological Processes, vol. 26, no. 11, pp. 1748-1750, 2012.

[42] PUB, Flash Flood Advisory October 2014, http://www.pub.gov .sg/managingflashfloods/SafetyAdvisory/Documents/FlashFloodAdvisory2014.pdf.

[43] C. Kennedy, "Flooding in Singapore: an overview," Proceedings of Future Floods: An Exploration of a Cross-Disciplinary Approach to Flood Risk Forecasting, FASS Environment Research Cluster, the Institute of Water Policy (Lee Kuan Yew School of Public Policy) and AON Benfield Pte. Ltd, https:// blog.nus.edu.sg/environmentcluster/files/2015/03/FUTUREFLOODS-NUS-Workshop-Claire-Kennedy-11cg2j1.pdf.

[44] W. Cai, S. Borlace, M. Lengaigne et al., "Increasing frequency of extreme El Niño events due to greenhouse warming," Nature Climate Change, vol. 4, no. 2, pp. 111-116, 2014.

[45] W. Cai, A. Santoso, G. Wang et al., "Increased frequency of extreme Indian ocean dipole events due to greenhouse warming," Nature, vol. 510, no. 7504, pp. 254-258, 2014. 
[46] P. P. Wong, "Impact of a sea level rise on the coasts of Singapore: preliminary observations," Journal of Southeast Asian Earth Sciences, vol. 7, no. 1, pp. 65-70, 1992.

[47] National Climate Change Secretariat (NCCS), Singapore's Approach on Adaptation, 2012, https://www.nccs.gov.sg/nccs2012/singapores-approach-on-adaptation.html.

[48] E. Rignot, J. Mouginot, M. Morlighem, H. Seroussi, and B. Scheuchl, "Widespread, rapid grounding line retreat of Pine Island, Thwaites, Smith, and Kohler glaciers, West Antarctica, from 1992 to 2011," Geophysical Research Letters, vol. 41, no. 10, pp. 3502-3509, 2014.

[49] I. Joughin, B. E. Smith, and B. Medley, "Marine ice sheet collapse potentially under way for the Thwaites Glacier Basin, West Antarctica," Science, vol. 344, no. 6185, pp. 735-738, 2014.

[50] URA (Urban Redevelopment Authority), Master Plan 2014, 2014, https://www.ura.gov.sg/uol/master-plan.aspx?pl=ViewMaster-Plan\&p2=master-plan-2014.

[51] National Population and Talent Division (NPTD), A Sustainable Population for a Dynamic Singapore: Population White Paper, 2013, http://population.sg/whitepaper/. 

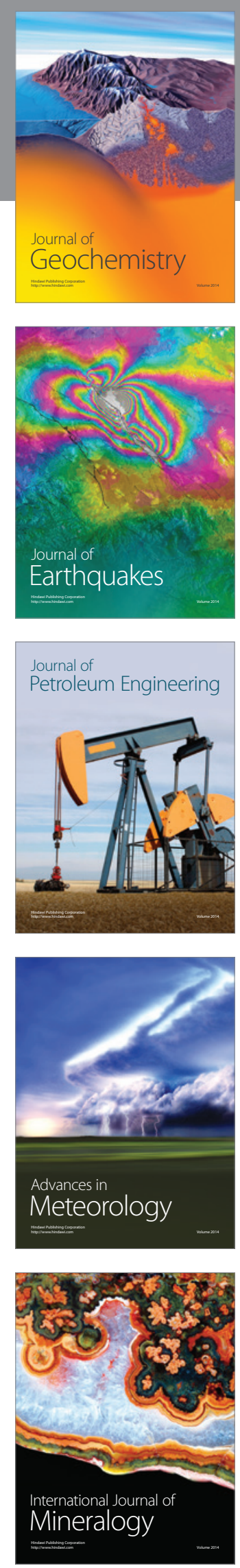
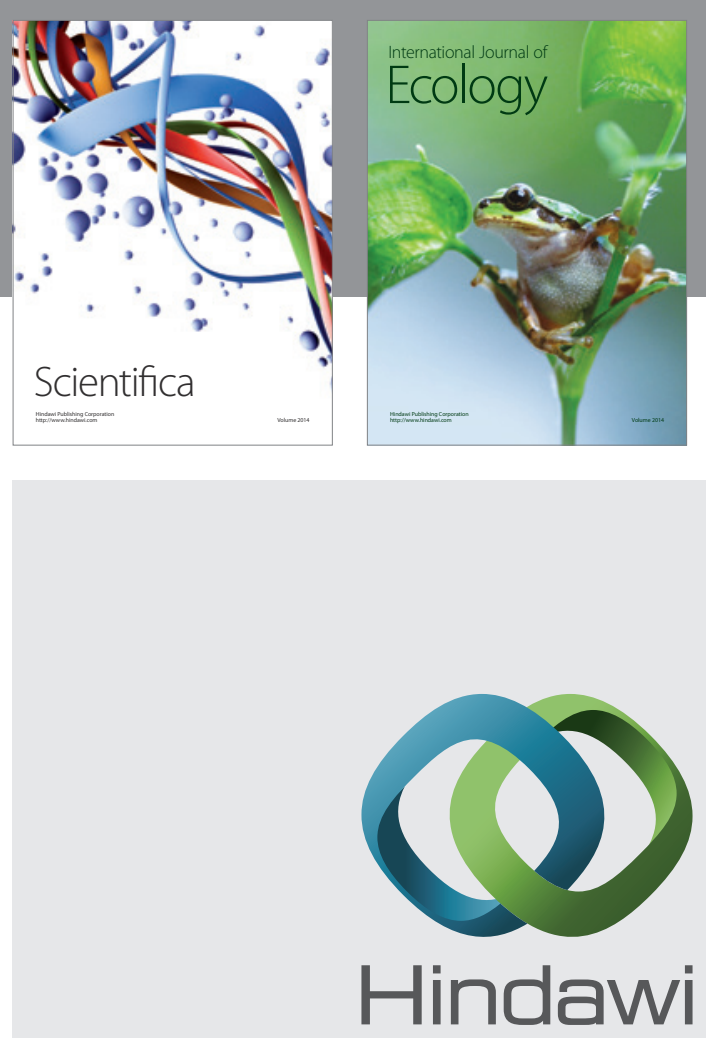

Submit your manuscripts at

http://www.hindawi.com
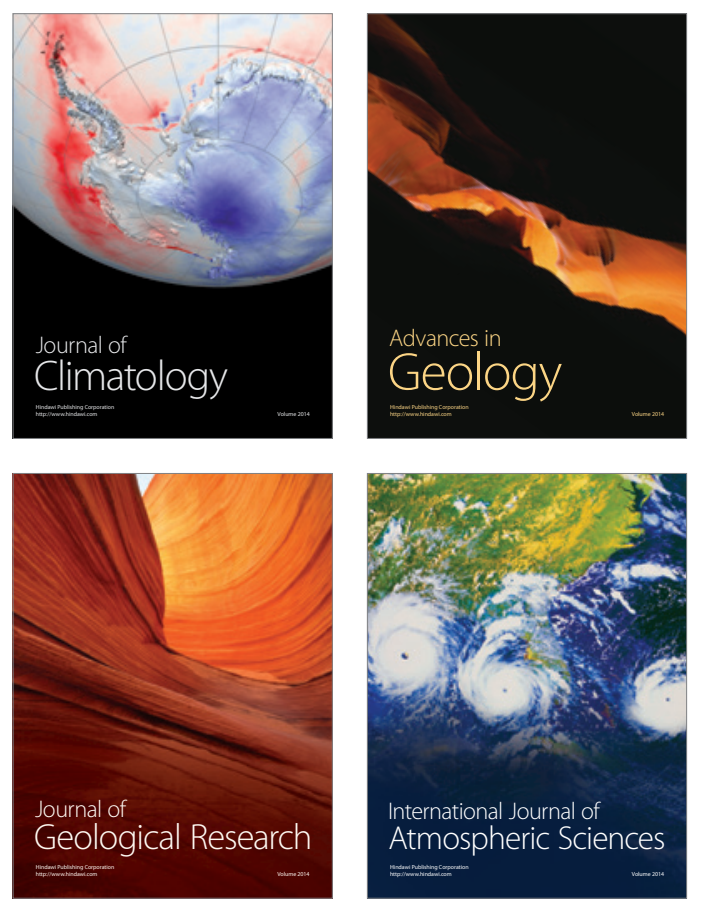

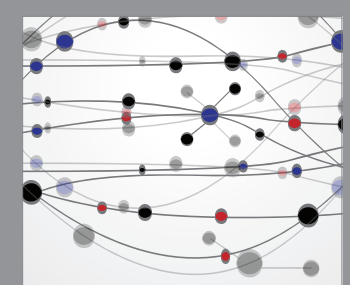

The Scientific

\section{World Journal}
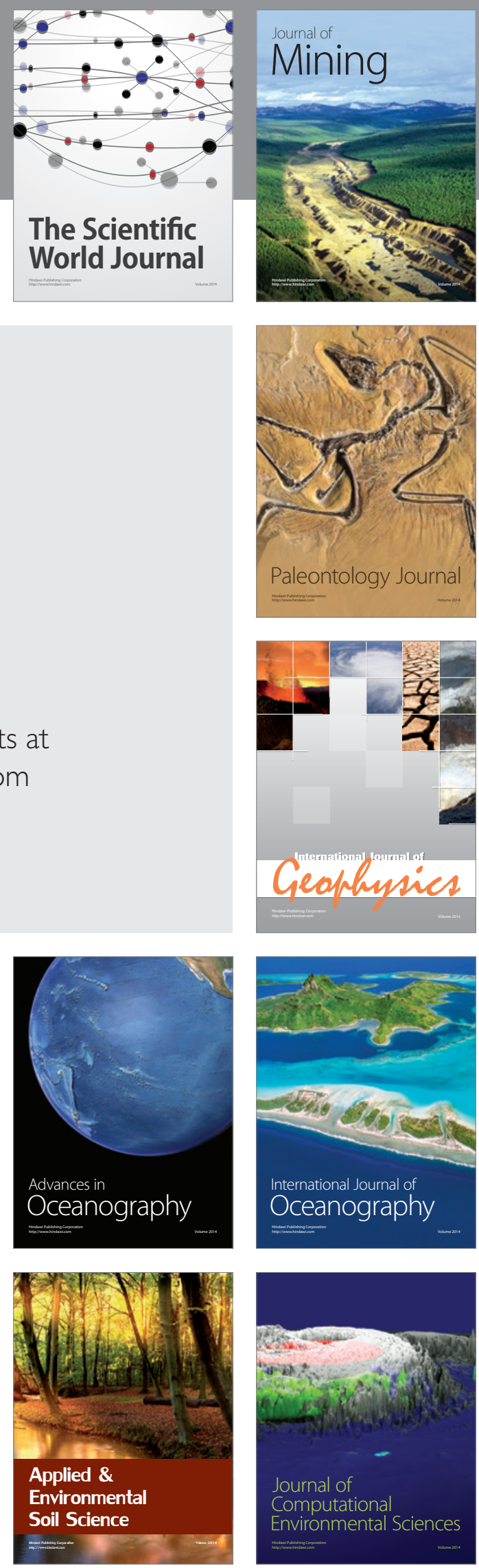